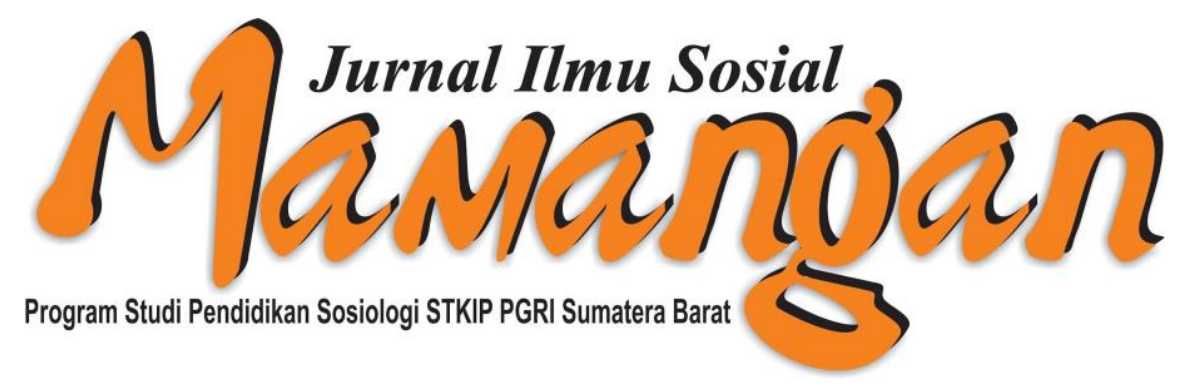

Jurnal Ilmu Sosial Mamangan

Volume 9, Issue 2, December, 2020

Social Capital Of Galian Owners In Maintaining Galian C In Mawar Hamlet, Kumbang Village, Pelangi District, Pasuruan Regency

Author (s) : : Ika Nursyafitri, Nyimas Nadya Izana

Source $\quad$ : Jurnal Ilmu Sosial Mamangan, Volume 9, Issue 2, December, 2020

Publisher : : Laboratorium Pendidikan Sosiologi, STKIP PGRI Sumatera Barat

To Cite This Article:

Nursyafitri, Ika; Izana, Nyimas Nadya, 2020. Social Capital Of Galian Owners In Maintaining Galian C In Mawar Hamlet, Kumbang Village, Pelangi District, Pasuruan Regency. Jurnal Ilmu Sosial Mamangan, Volume 9, Issue 2, December, 2020: 103-112

Copyright (C) 2020, Jurnal Ilmu Sosial Mamangan

ISSN: 2301-8496 (Print) \& 2503-1570 (Online) 


\title{
Social Capital of Galian Owners in Maintaining Galian C in Mawar Hamlet, Kumbang Village, Pelangi District, Pasuruan Regency
}

\author{
Ika Nursyafitri ${ }^{1}$, Nyimas Nadya Izana ${ }^{2}$ \\ Universitas Brawijaya \\ ${ }^{1}$ Ika Nursyafitri \\ Email : nursyaaikaa@gmail.com \\ 2Nyimas Nadya Izana \\ Email: nyimasnadyaizana@gmail.com
}

\begin{abstract}
Social Capital of Galian Owners in Maintaining Galian C in Mawar Hamlet, Kumbang Village, Pelangi District, Pasuruan Regency, Ika Nursyafitri, Nyimas Nadya Izana, nursyaaikaa@gmail.com, nyimasnadyaizana@gmail.com

Mining in Mawar Hamlet, Kumbang Village, Pelangi District, Pasuruan Regency is a type of illegal mining, but mining activities have been carried out since 1984 until now. So this research aims to analyze the social capital of the owner of the excavation in maintaining the $C$ quarry in the Rose Village with the established network. The method used is a qualitative research method to explore more complete data, and uses a case study approach because an incident in 2015 was marked with the issue of illegal mining permits that were evicted by the Civil Service Unit (Satpol PP of Pasuruan Regency). This study uses the theory proposed by Pierre Bourdie about social capital. Social capital can be related to economic capital, cultural capital, and symbolic capital. Thus, the emergence of the capital generated by the owner of the excavation originated from the habitus as a daily habit carried out by the agent, the network relationships formed were also strategies to strengthen the agent's position.
\end{abstract}

\section{Keywords: Social Capital, Galian C Mining, Illegal Mining}

\section{INTRODUCTION}

Mining excavation $\mathrm{C}$ is a mining business which consists of exploration, exploitation, processing or refining, transportation and sale of class C minerals
(Rizkiana, 2012). In quarry mining $C$, there are several factors in the management of quarry $\mathrm{C}$ according to (Rissamasu, Darma, \& Tuwo, 2011) is processing of mineral $C$ can be seen in terms of intensification and extensification, as well as from regulations, professionalism, 
and the level of compliance of the mining community reggarding licensing. Mining and quarrying $C$ according to (Souisa, 2016) can be classified into 9 groups, among others: yarocyte, nitrate, asbestos, gemstones, sand, limestone, granite, pumice, and marble.

The sand minning in Mawar Hamlet, Kumbang Village, Pelangi District, Pasuruan Regency included in the illegal mining category that does not yet have an official mining permit. This mining was founded in 1984 until now which is owned by individuals. This is able to lead to the researcher's analysis, namely how the mining owner's social capital can sustain the illegal mining. Things appear at the mine at the time of the researchers to collect data, mining of sand and stone impact for the local community. The impacts that arise are first, positive impacts. The positive impact of the mine could create jobs for local people, for local people only job in the mining sector. So, the existence of this mining is able to increase income to meet daily needs. The positive impact of mining can help in the community's economy, as the researcher cites from the research (Widyastomo \& Risyanto, 2013) that mining products in Kemalang District provide potential for natural wealth in A the form of soil fertility, wealth of minerals (sand and stone), tourism and culture so that they become a strong attraction for residents to live around volcanoes. Also according to research by (Sugiarto \& Hariyanto, Tinjauan Kriminologis Terhadap Kejahatan Pertambangan , 2018) that the existence of mining $\mathrm{C}$ excavation $\mathrm{C}$ can provide profit benefits to both investors and the state, and create jobs. Also according to (Ghazalie, Rahmawati, \& Elsera, 2017) that the positive impact is also due to the existence of large investors who can organize quite well in illegal mining.

Second, the negative impact. The negative impact of this mining is the existence of a mining location adjacent to the Dragon Lake, this has occurred floods, eroded soil due to the dredging of sand and rock every day. Also, the process of transporting sand and stones can damage road access to the mining site. With this, the main point of this illegal mining is still being carried out as the network formed by the mining owner is getting stronger. The negative impact of mining also arise due to complaints from the public, as the authors cite research (Adenisatrawan \& Yadin, 2019) that the effect of exploration and production of the nickel mine of PT. Sambas Minerals Mining and PT Macika Mada Madana in Palangga Selatan Subdistrict cause a high volume of floods in every rainy season, silting rivers, sandy rice fields and others. Also, according to research results by (Hariyanto, 2016) that the existence of sirtu sand mining leads to a negative impact because the community feels pressured by the transfer of jobs, which initially worked as farmers, now work as managers. This means that the community must be able to enable themselves to work in the mining sector (Hariyanto, 2016). According to (Widya, Setiani, \& Dangiran, Hubungan Intensitas Kebisingan Dengan Tekanan Darah Sistolik Dan Diastolik Pada Pekerja Pertambangan Pasir dan Batu PT. X Rowosari, Semarang, 2018) that the existence of mining activities that are carried out every day can generate noise that affects public health which causes stress.

According to (Rohmah, Muchsin, \& Hayat, Upaya Pemerintah Daerah Kabupaten Pasuruan Dalam Penanganan Dampak Pertambangan, 2017) that the existence of mining excavation must pay attention to environmental management efforts (UKL) and environmental monitoring efforts (UPL) so that the surrounding environmental conditions and the community can run optimally.

The emergence of mining in an area does increase investment or income for that area, but the mining location in Mawar Hamlet does not have an official license and is owned by individuals. Quoted from the Regional Regulation of Pasuruan Regency Number 2 of 2011 in Article 46 regarding the selling value calculated by multiplying the volume or tonnage of the harvest by the market value or standard price of each type of non-metal mineral and rock. The market value used for the standard is determined by the Regional Head. The tax rate for non-metal minerals and rocks is set at $25 \%$. According to the results field, in a mine in Mawar Hamlet do not pay the $25 \%$ tax levy but only pay a road tax of Rp $5,000.00$ to the local community that has land access to the mine site. With this, it actually gives the excavation owner the opportunity to 
relax and there is no burden to pay local tax levies, which should be the duty of a dig owner to comply with the Regional Regulation.

In 2014, through the Environmental Service, the Regional Government had not issued mining permits and was taken over by the Province of East Java in accordance with Law Number 23 of 2014 concerning Regional Government. And the Department of the Environment also provides recommendations according to the Regional Regulation on Spatial and Regional Planning (RTRW). With this change in policy from the Regional Government, the excavation owner's awareness is still in the low category because the excavation owner should already know the permit letter regarding the mining, but the motivation to dredge sand and get a large profit has made the owner of the excavation not take care of it. And if there is a permit and take care of it with the East Java Province regarding mining, then the obligation of the owner of the excavation must pay retribution or taxes to the Regional Government, as well as provide participation funds to the local environment. As stipulated in the Government Regulation of the Republic of Indonesia Number 37 Year 1986 regarding mining, it must have an official permit. However, the mining in Mawar Hamlet does not yet have an official mining permit and there are a number of cases that have occurred. The series of cases that occurred in 2015 saw a breakdown by the Pasuruan Regency Civil Service Unit to stop mining activities at the location, so that the excavation owner and the community demonstrated and the excavation owner urged that this case be quickly resolved. Then, about one week the local community automatically opened the illegal mining because it was to meet their daily needs.

With this case being the focus of this research, the researcher uses the theoretical basis of social capital by Pierre Bourdieu as a reference to analyze what capital the excavation owner has in maintaining the illegal mining $\mathrm{C}$ mining in the Mawar Hamlet which has a negative impact on the community and the surrounding environment. By using the theoretical basis of social capital by Pierre Bourdieu, researchers as conducting research at the Mawar Hamlet can explain how the relationship or interaction between agents, including the village apparatus, the Civil Service Unit of Pasuruan Regency as the dominant agent, and the owner of the quarry, mining workers, and mining driver as subordinate agent. This agent is formed through habitus, domain, and strategy. Then, the relationship between the two agents will produce some capital (economic capital, cultural capital, social capital, and symbolic capital). (Krisdinanto, 2014). The existence of this realm also creates a relationship or relationship into a habit that is carried out by agents to build strong relationships in the mining. Thus, the researcher as finding data in Mawar Hamlet can explain what social capital is owned by the owner of the excavation in maintaining the illegal mining $\mathrm{C}$ excavation in Mawar Hamlet today. Social capital is any kind of relationship as a resource for determining the social position (Supono, 2011). This social capital theory will carry out an analysis of a habitus. Habitus according to (Affandi, Chawa, \& Nuryani, 2018) are actions taken by actors to face social life. The realm (a network of relationships formed by each agent), thus generating some capital (economic, cultural, social, and symbolic), can also use strategies to strengthen the position of agents to get some of this capital, including reproductive strategies and reconstruction strategies.

\section{RESEARCH METHODS}

In research methods, there are several types, namely quantitative, qualitative and mixed research methods. Researchers use qualitative research methods, this is because researchers want to find and dig deep information related to the social capital of the owner of the excavation in maintaining the $\mathrm{C}$ excavation mine in the Mawar Hamlet. In qualitative research methods, there are several approaches which ethnography, phenomenology, and case studies. Researchers used a case study approach. The reason the researchers used a case study research approach was because there were cases that occurred in 2015 related to mining licensing. The case was conducted by the Unit of the Civil Service Pasuruan to illegal mining sites in the Mawar Hamlet. Researchers used a variant of the instrumental model case study. 
The pre-research time was carried out by researchers in field observation activities, namely on January 12, 2019, mining excavation $\mathrm{C}$ at Mawar Hamlet. The time for field visits to conduct interview activities was in accordance with the informant's research subjects, namely on September 5, 2019 to September 23, 2019. In the informant determination technique, researchers used the purposive informant determination technique because not all samples had criteria that were in accordance with the phenomenon under study. Therefore, researchers need certain considerations or criteria to be used in research. In this study, a sample of which the owner of the quarry, the driver, and the workers at the mine site.

After the researchers carry out research activities at the mine site illegally in Mawar Hamlet, in section data collection techniques include observation, interviews, documentation and literature researchers focused-related cases in 2015 concerning the licensing of illegal mining, the presence of illegal mining is capable of directing the the social capital of the owner of the excavation in maintaining the $\mathrm{C}$ excavation mine in Mawar Hamlet, Kumbang Village, Pelangi District, Pasuruan Regency. Thus, the researcher decided to analyze the research using direct interpretation model analysis techniques.

The researcher decided that the case being investigated by the researcher was with the existence of illegal mining from 1984 to the present at Mawar Hamlet, also in 2015 there was a case regarding mining permits which led to the social capital of the owner of the excavation in maintaining the $C$ excavation mining in Mawar Hamlet, Kumbang Village, Pelangi District, Pasuruan Regency.

On the social capital of the shipyard owner, the researcher provides a kind of coding on the subject source related to the social capital of the owner of the excavation in maintaining the $\mathrm{C}$ excavation mine in the Mawar Village. The first subject gave the code "A", the second subject gave the code "B", the third subject gave the code "C", and the fourth subject gave the code "D". With this, the researcher can focus the informant's data according to the problems that occur so that the results of the data obtained are accurate, according to what was done at the time of the research. Also, research can be said to be valid, it can use triangulation. Triangulation according to Sugiyono, 2012 in (Harwon, 2015) can be classified into 3 types, among others: triangulation, triangulation techniques, and triangulation of time. In this study, researchers used source triangulation to check and test the data so that they were valid by using interview, observation, and documentation methods.

\section{RESULT AND DISCUSSION}

As a result of stabilizing the material related to the theoretical basis of social capital, according to Pierre Bourdieu, the researcher can write in this study that social capital is one of the instruments as a result of habitus and the realm. Habitus here comes from daily habits carried out by individuals in a place. The emergence of habitus can form individual characters because it is durable in relationships between individuals and forms into groups. These groups will later change the social class in society.

The realm here comes from all kinds of conditions that occur in society, both in the form of structures, rules, values and norms that exist in society and others, which will be able to coincide with the conditions that occur in the community. Habitus and realm are formed from a network of relationships that are formed by one individual to another in conditions of the community environment. In essence, it is these habitus and realm that form capital (economic, cultural, social, and symbolic). With this realm, it will also become a community forum to shape one's personality, which will later become a place for social struggles that occur within the community.

Habitus and realm here have the most important points which become the theoretical foundations used by researchers as a result of the formation of types of capital (economic, cultural, social, and symbolic). In society, the relationship between one individual and another as well as the emergence of a habitus will form a realm and capital that the individual has. This is able to create various structures, power, domination and others that exist in the community. Capital here aims as an impetus which is the result of 
the habitus and realm, as well as as a force operating in that realm. The realm has the urge to form in every space of society so that individuals compete with each other. Thus, the emergence of the realm and capital within the community becomes the strength of the individual to own the type of capital (economic, cultural, social, and symbolic). With this, it is also created that the existence of this realm and capital encourages people to be able to survive. Habitus here is defined as a structural structure in social life.

This can be indicated by the ongoing mining activities, the people in the Mawar Hamlet have a habit of being actors in sand and stone mining activities. At the mining location, some people work as sand and stone mining laborers, mining owners, and drivers. Sand and stone mining activities have been going on since 1984 until now and have the status of being owned by individuals and do not have a mining permit. This has become a habit of the local community as a form of habitus although mining of sand and stones in the Mawar Hamlet does not yet have a mining license, but the owner thinks it is used to open up jobs for local people, so that the associated legality has not been optimized. And workers with mining status who do not have a mining permit (illegal) are not so important, because workers or laborers have the aim to get only and minimal financial benefits related to environmental problems related to mining which are excavated every day with a location next to Dragon Lake.

In this study, the researcher looked at the habitus of dominant agents (Civil service police unit of Pasuruan Regency and village apparatus elites) and subordinate agents (excavation owners, mining workers, and drivers at mining sites) in defending illegal mining in Mawar Hamlet. Thus, the subject of this study is a group. Therefore, in analyzing the phenomena in this study, the researcher used the concept of class groups. The concept of class groups according to (Affandi, Chawa, \& Nuryani, 2018) are elements that organize practices so that agents can produce practices of equal status. It is meant as a system producing practice, perception and appreciation of practices.

Habitus in the mining location which is formed from mining workers, drivers, and excavation owners provides a pattern of perceptions (point of view), appreciation (choices), and actions taken by all actors in an arena that is durable and can change. First, the perspective of mining workers at the mining site thinks that working at a mining site has a positive impact on the local community. With this mining, workers can work and earn money to meet their daily needs. Also the perspective of workers related to illegal mining is not really discussed, because the guidelines for workers in the presence of illegal mining only rely on profits or results so that legality has not been optimized. With this, it is able to direct the workers' view, primarily for economic gain, in order to defend the illegal mining in the Mawar Hamlet by establishing a strong network with the excavation owners. Also the excavation owner maintains a strong network of relations with the civil service police unit, with evidence of workers dredging sand every day and the civil service police unit supervising workers so that the workers do dredging with caution.

Second, the point of view of the driver at the mining location is that this mining is to generate work for the local community, the driver has the habit of making payments before going to the mining location by paying road tax to the landlord of Rp. 5.000,00 also establish network relations with the owner in order to maintain the illegal mining in the Mawar Hamlet. The excavation owner also has a strong network with the civil service police unit so as not to carry out evictions at the mining site.

Third, the perspective of the owner of the excavation at the mining location, with the provenance of the mining area with an area of around 13,000 hectares, is the potential for the owner of the excavation to take advantage of this potential. By establishing a strong network relationship according to the capital owned to maintain the illegal mining $\mathrm{C}$ mining in the Mawar Hamlet. The owner of the excavation has a goal of instructing workers to do daily dredging of sand and stone which will later be useful for plantation land. Also the owner of the excavation, related to legality is less optimized but has made strong relations by spending money by giving tips (money) to the dominant party (the civil service police unit) so that supervision at the illegal mining 
site in the Mawar Hamlet is not tightened. With this, the owner of the excavation was able to defend the illegal mining $C$ excavation in the Mawar Hamlet.

The realm as a network of relationships carried out by one individual to another within the community, which will later give rise to capital (economic, cultural, social, and symbolic). In the realm that appears in this study, researchers can analyze that the network formed in the sand and rock mining with mining status does not have a mining permit (illegal), the owner of the excavation in maintaining the $\mathrm{C}$ excavation mining in the Mawar Hamlet by involving several informants, including others: mining owners, workers (laborers), and drivers.

In the theory put forward by Pierre Bourdieu about social capital, it has something to do with contestation (struggle). The emergence of this contestation originated from an analysis of economic capital as a result of the benefits obtained from each individual. This contestation (struggle) arises with the aim of gaining a position in an arena. The arena referred to here is the illegal mining location in the Mawar Hamlet. From this it became a battle for the actor to fight for his main position to defend the illegal mining in the Mawar Hamlet. In order to become a battle in this space and arena, the appearance obtained will change. This change is marked as the weakening of the agent to occupy his position. Agents here can be classified into two, namely agents of upper domination (state party: civil service police units, village elites) and lower domination (excavation owners, workers, and drivers). This is done to position themselves as well as distribute the capital they own.

There are also strategies to strengthen the position of agents in obtaining capital, which are grouped into two types, namely reproductive strategies and reconversion strategies. According to the results of the field conducted by researchers in their research, the reproductive strategy is characterized by the emergence of a habit carried out by actors (excavation owners, workers, and drivers) at the mining location with an agreement on salaries and road tax payments to maintain illegal mining in the Mawar Hamlet. Also, the reconversion strategy that emerged was marked by the presence of production equipment (land) with an area of around 13,000 hectares at the mining site, which became a means for the ability and expertise of the owner to have a wide network between excavation owners as well as relationships with village elites to buy village asset land because of the funds that were received in the village is inadequate, also the party with the civil service police unit, the owner of the excavation, provides tips (money) so that it is not carried out strictly operating at the mining location as one of the main ways to defend illegal mining in the Mawar Hamlet. 
The fighting schemes that occur in the realm aspect as a network of relationships that are formed related to the social capital of the owner of the excavation in maintaining the C excavation mine in the Mawar Hamlet include:

\section{Scheme 1. Mining Realm Scheme in Mawar Hamlet, Kumbang Village, Pelangi District, Pasuruan Regency}

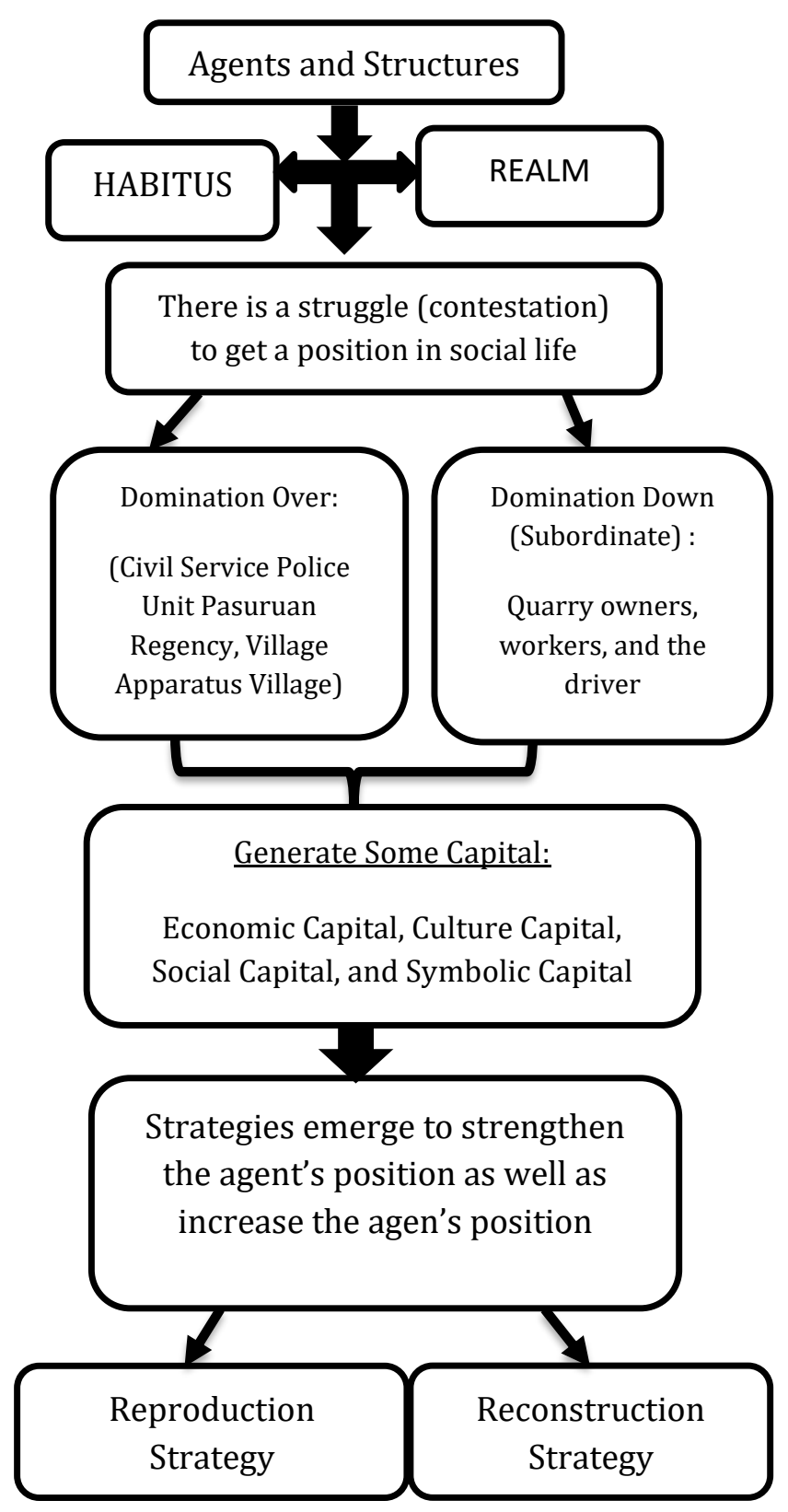

Source: Data Processed by Researchers, 2019

The economic capital that appears in this study, the researcher found that in this mining location, there is a relationship between one individual and another, for example between workers and mining owners who can make a relationship in financial terms. Economic capital here is characterized by the presence of capital which can be directly exchanged as individual property. Property rights are meant here, such as ownership of the means of production (machines, land, labor and others), as well as material (income). Cultural capital here refers more to the intellectual abilities of individuals obtained from the point of view of formal and informal education as one of the family inheritances. The cultural capital that appears here is the expansion of the mining area of around 13,000 hectares, so that the owner of the excavation takes advantage of this potential. By establishing a strong network relationship according to the capital owned to defend the illegal mining in the Mawar Hamlet.

Social capital here is visible, such as forming networks owned by actors (excavation owners, workers, and drivers) in relation to the domination of the top (the village apparatus, the civil service police unit) in order to defend the illegal mining in Mawar Hamlet. Also, the symbolic capital here which appears to be a high status in accordance with the adequate capital owned by the excavation owner, the dominating actor (the civil service police unit) does not provide a strict extension of the operation at the illegal mining site in Mawar Hamlet. So, this mining is carried out every day dredging of sand and rock.

The symbolic capital related to illegal mining in Mawar Hamlet focuses more on the relationship between economic capital, cultural capital and social capital. This seems to appear to position the agent in an arena. The dominant agents in mining locations are state elites such as village officials, who initially this mining land was a village asset, then sold it to the owner of the capital (the owner of the excavation), also in 2015 related to mining permits, the mining location was temporarily closed because mining was illegal and there was an eviction carried out by the Pasuruan Regency Civil Service Unit. Subordinate agents here are agents who are involved in mining locations every day, such as workers, drivers, and excavation owners.

With the existence of illegal mining, the emergence of dominant agents (village 
officials, the Civil Service Unit of Pasuruan Regency) and subordinate agents (excavation owners, workers at mining sites, and drivers at mining sites) shows the relationship between economic capital, cultural capital and social capital. Then, with proof of economic capital, namely the existence of illegal mining in the Mawar Hamlet, it is able to encourage the benefits obtained by workers and drivers in the form of money to meet their daily needs. Cultural capital can be seen in the case of illegal mining when there is a mining area of around 13,000 hectares, the owner of the excavation takes advantage of this potential by forging strong network relationships according to the capital owned which aims to maintain illegal mining in the Mawar Hamlet. On the other hand, there is social capital when there are dominant agents (civil service police units and village officials) and subordinate agents (excavation owners, workers, and drivers) who are able to establish very strong relationships to defend the illegal mining. It is also able to provide a position to achieve their respective goals. Thus, a symbol appears, namely the high status of the excavation owner aimed at maintaining illegal mining in Pasuruan Regency.

\section{CONCLUSION}

The social capital of the owner of the quarry in maintaining the $\mathrm{C}$ quarry at the Mawar Hamlet uses the theoretical approach by Pierre Bourdieu regarding social capital. After conducting observations, interviews with the local community and the owner of the excavation at the sand mining site in Mawar Hamlet, the social capital that appears here will be analyzed by researchers. Social capital according to Pierre Bourdieu that social capital here is divided into 4, namely socioeconomic capital, cultural capital, social capital, and symbolic capital. Apart from that, according to Pierre Bourdieu, social capital is social capital that is related to other concepts of power, namely the habitus and the realm.

Habitus here is a structured structure of social life. The realm here comes from all kinds of conditions that occur in society, both in the form of structures, rules, values and norms that exist in society and others, which will be able to coincide with the conditions that occur in the community. Habitus and realm are formed from a network of relationships that are formed by one individual to another in conditions of the community environment. In essence, it is these habitus and realm that form capital (economic, cultural, social, and symbolic). The social capital of the owner of the excavation in maintaining the $\mathrm{C}$ excavation mining in Mawar Hamlet, as the result of data mining in the field, is that mining activities have been ongoing since 1984 until now with the mining status that does not have an official mining permit, but the owner, workers and drivers continue to carry out mining for meet daily needs, so that related legality has not been optimized.

Thus, a network of relationships is formed by involving several informants, namely mining owners, workers at mining sites, and drivers who work at mining sites. There are 4 capital that appears, namely economic capital with the main objective of obtaining financial benefits at mining sites, cultural capital as one of the intellectual abilities of individuals in terms of formal and informal education, information, and others. Social capital here is formed by a relationship between upper domination (village elites, civil service police units) and lower domination (excavation owners, workers, and drivers) in order to maintain illegal mining in the Mawar Hamlet. Also symbolic capital appears because of the existence of a symbol of ownership of the high status of the owner of the excavation as a strengthening of capital ownership with the aim of maintaining the C-quarry mining in Mawar Hamlet, Kumbang Village, Pelangi District, Pasuruan Regency. The suggestions in this study include :

1. The Pasuruan Regency Government should make an effort to follow up on illegal mining so as not to give permits carelessly. And the point is there is no link between several individuals for the satisfaction of the goals of each individual.

2. The village government in a part of Pasuruan Regency should make efforts to make mining activities in the Mawar Village become mining activities with legal status. 
3. The local community at the mining site does not pay attention to environmental conditions characterized by excessive dredging of sand and rock every day which will have a negative impact on the environment such as the emergence of erosion, flooding, and adjacent lakes will cause damage to habitats and environmental ecosystems.

4. For further researchers, it is suggested to further assist the researchers' suggestions for the Regional Government of Pasuruan Regency, the villa ge government, and even the local community at the mining site to follow up on the problem of illegal mining in Mawar Hamlet.

\section{REFERENCES}

Adenisatrawan, \& Yadin, Y. I. (2019). Pola Penanggulangan Kerusakan Lingkungan Efek Eksplorasi dan Produksi Tambang Nikel PT. Sambas Minerals Mining dan PT. Macika Mada Madana (Studi Kasus Kec. Palangga Selatan, Kab. Konawe Selatan). Jurnal Al-'Adl, Vol. 12 No. 1, 135-153.

Affandi, G. I., Chawa, A. F., \& Nuryani, A. F. (2018). Strategi Paguyuban Pencak Silat Tradisional Bintang Timur Dalam Melestarikan Kesenian Can Macanan Kadduk. Jurnal Kajian Ruang SosialBudaya, 1-11.

Bakri, S. (2018). Peran Pemerintah Daerah Dalam Pengendalian Kerusakan Lingkungan Akibat Pertambangan Emas Ilegal di Sungai Mandor Kabupaten Landak. Jurnal Nestor Magister Hukum Vol 3, No 3, 1-7.

Ghazalie, A. M., Rahmawati, N., \& Elsera, M. (2017). Jaringan Sosial Penambang Timah Tradisional Pasca Larangan Tambang Inkonvensional (Studi Pada Masyarakat Penambang Timah Kampung Boyan Desa Batu Berdaun Kecamatan Singkep Kabupaten Lingga). Jurnal 55, 1-21.
Hariyanto, A. (2016). Refleksivitas Masyarakat Bulusari Terhadap Pertambangan Sirtu di Gunung Perahu Kecamatan Gempol Kabupaten Pasuruan. Digital Repository Universitas Jember, 1-7.

Harwon, W. P. (2015). Analisa Perencanaan Suksesi Pada UD. Hoki Jaya. AGORA Vol. 3, No. 1, 554-557.

Krisdinanto, N. (2014). Pierre Bourdieu, Sang Juru Damai. KANAL, 107-206.

Rissamasu, F., Darma, R., \& Tuwo, A. (2011). Pengelolaan Penambangan Bahan Galian Golongan C Di Kabupaten Merauke. 54-55.

Rizkiana, R. D. (2012). Pengelolaan Usaha Penambangan Bahan Galian Golongan C DI DESA Darmakradenan Kecamatan Ajibarang Kabupaten Banyumas. 13.

Rohmah, S., Muchsin, M. B., \& Hayat. (2017). Upaya Pemerintah Daerah Kabupaten Pasuruan Dalam Penanganan Dampak Pertambangan. Journal of Indonesian Public Administration and Governance Studies (JIPAGS), Volume 01 Nomor 02, 160-168.

Rusnama, I. S., Widiati , I. A., \& Sugiartha, I. G. (2019). Sanksi Pidana Pertambangan Pasir Tanpa Izin (Studi Putusan Nomor 120/Pid.Sus/2017/PN Gin). Jurnal Analogi Hukum, 384-389.

Souisa, R. (2016). Pengelolaan Pertambangan Batu Bacan Oleh Pemerintah Kabupaten Halmahera Selatan. 52.

Sugiarto, T., \& Hariyanto, B. (2018). Tinjauan Kriminologis Terhadap Kejahatan Pertambangan Tanpa Izin di Kabupaten Lumajang. Ar-Risalah, Vol. XVI, 114-126. 
Supono, B. (2011). Peranan Modal Sosial Dalam Implementasi Manajemen dan Bisnis. Jurnal Ekonomi dan Kewirausahaan Vol. 11, 10-16.

Widya, M., Setiani, O., \& Dangiran, H. L. (2018). Hubungan Intensitas Kebisingan Dengan Tekanan Darah Sistolik dan Diastolik Pada Pekerja Pertambangan Pasir dan Batu PT. X, Rowosari, Semarang. JURNAL KESEHATAN MASYARAKAT (e-Journal), Volume 6, Nomor 6, 225-234.

Widyastomo, B., \& Risyanto. (2013). Pengaruh Penambangan Pasir dan Batu Terhadap Kondisi Sosial Ekonomi Penambang di Kecamatan Kemalang Kabupaten Klaten, Provinsi Jawa Tengah. 271.

Yani, R. F. (2019). Peran WALHI Sumatera Barat dalam Investigasi Tambang Emas Ilegal di Kota Padang. 1-5. 